\title{
EVALUATION OF DROUGHT TOLERANCE INDICES FOR BARLEY LANDRACES UNDER IRRIGATED AND DRY CONDITIONS
}

\author{
AVALIAÇÃO DE ÍNDICES DE TOLERÂNCIA SECA PARA TERRAÇOS DE CEVADA \\ EM CONDIÇÕES IRRIGADAS E SECAS
}

\section{Mehdi FEIZI $^{1 *}$; Mahmoud SOLOUKI ${ }^{2}$; Behzad SADEGHZADEH ${ }^{3}$; Baratali FAKHERI $^{2}$; Seyed Abolghasem MOHAMMADI ${ }^{4}$}

1. Ph.D. student of Plant Breeding, University Campus, Department of Plant Breeding and Biotechnology, University of Zabol, Zabol, Iran. mehdi.feizi.64@gmail.com; 2. Department of Plant Breeding and Biotechnology, Faculty of Agriculture, University of Zabol, zabol, Iran, mahmood.solouki@gmail.com; 3. Dryland Agricultural Research Institute (DARI), Agricultural Research, Education and Extension Organization (AREEO), Maragheh, Iran, behzada4@yahoo.com; 4. Department of Plant Breeding and Biotechnology, Faculty of Agriculture, University of Tabriz, Tabriz, Iran, sa_mohammadi@yahoo.com.

\begin{abstract}
Barley cultivation for drought areas requires a reliable assessment of drought tolerance variability among the breeding germplasms. Hence, 121 barley landraces, advanced breeding lines, and varieties were evaluated under both moisture non-stress and stress field conditions using a lattice square $(11 \times 11)$ design with two replications for each set of the trials. Twelve drought tolerance indices (SSI, TOL, MP, GMP, STI, YI, YSI, HM, SDI, DI, RDI, and SSPI) were used based on grain yield under normal (Yp) and drought (Ys) conditions. Analysis of variance showed a significant genetic variation among genotypes for all indices except for TOL and SSPI indices. Yp had a very strong association with Ys $\left(r=0.92^{* *}\right)$ that indicates high yield potential under non-stress can predict better yield under stress conditions. Yp and Ys were positively and significantly correlated with MP, GMP, STI, YI, HM, and DI indices, whereas they were negatively correlated with SSI and SDI. In principal component analysis (PCA), the first PC explained $64 \%$ of total variation with Yp, Ys, MP, GMP, STI, YI, HM, and DI. The second PC explained $35.6 \%$ of the total variation and had a positive correlation with SSI, TOL, SDI, and SSPI. It can be concluded that MP, GMP, STI, YI, HM and DI indices with the most positive and significant correlation with the yield at both non-stress and stress environments would be better indices to screen barley genotypes, although none of the indices could undoubtedly identify high yield genotypes under both conditions.
\end{abstract}

KEYWORDS: Drought Index. Principal component analysis. Germplasm. Yield.

\section{INTRODUCTION}

Drought is one of the most important abiotic stresses that adversely affects growth, metabolism, and yield of barley under dryland conditions. In arid and semi-arid climates, either reduction in water supply in soil or high transpiration rate can cause drought experience in crops (REDDY ET AL., 2004). Drought tolerance is based on different strategies like dehydration escape or avoidance and drought tolerance. Drought declines root growth, leaf water potential, cell membrane stability, photosynthetic rate, and carbohydrate accumulation (JIANG; HUANG, 2000; TARDIEU et al., 2014; ASSAHA et al., 2016).

Drought tolerance improvement has been a goal in crop breeding, although, success in breeding for tolerance has been restricted because this trait is quantitative and controlled by many genes (Von KORFF et al., 2008; WEHNER et al., 2016), dif ficult to eliminate adverse genes
(RICHARDS, 1996), lack of suitable screening procedures particularly under field conditions (KIRIGWI et al., 2004).

To identify drought-tolerant genotypes, yield stability of genotypes under both drought stress and optimum conditions is vital for plant breeders. Moreover, high-yielding genotypes under favorable conditions may not be drought tolerant (SIO-SE MARDEH et al., 2006); therefore, many researches preferred screening under stress and non-stress conditions (MOOSAVI et al., 2008). Wheat grain yield under non-stress conditions was negatively correlated with stress conditions, and a high potential yield under favorable conditions does not necessarily result in improved yield under stress conditions (SIO-SE MARDEH et al., 2006). Also, genotypes with high yield may not be stresstolerant, so increasing the yield in these genotypes may be especially due to their high potential yield (BLUM, 1996).

Different indices were introduced such as geometric mean productivity (GMP), stress 
susceptibility index (SSI), tolerance (TOL), mean productivity (MP), harmonic mean (HM), stress tolerance index (STI), yield index (YI), yield stability index (YSI), sensitivity drought index (SDI), drought response index (DSI), drought resistance index (DI), relative drought index (RDI), stress susceptibility percentage index (SSPI), and modified stress tolerance index (MSTI). These indices have been used to select stable genotypes according to their performance under stress and favorable conditions (ABEBE et al., 1998; MURSALOVA et al., 2015). A study on barley indicated that STI, MP, and GMP are the best criteria for screening high yielding genotypes under both stress and non-stress conditions (NAZARI; PAKNIYAT, 2010). However, screening of genotypes based on these criteria has generally been ineffective due to their higher relation with survival mechanisms in crops. Moreover, drought tolerance is connected with many other stress factors like salt, high temperature, senescence, development, cell circle, flowering, signal transduction, etc. In another word, drought stress is interconnected with almost all aspects of biology, and the recommendation of an appropriate index for its screening is really difficult and complex (MOOSAVI et al., 2008). So, none of the indices could effectively identify genotypes with high yield under both stress and non-stress conditions. The effectiveness of the indices in the screening depends on the stress severity (KUTLU; KINACI, 2010).

The relative yield performance of genotypes in stress and non-stress environments in small-size populations seems to be a common starting point in the identification of traits related to drought tolerance and the selection of genotypes in breeding for dry environments in so many studies. Because of the lack of enough genotypic variation in small-size populations, the effectiveness of these criteria in finding drought-tolerant genotypes are still controversial and questionable. In the same pattern, the selection in the current study was conducted under non-stress and stress conditions, but in a large population (121 very diverse barley population from all around the world) to empower the quality of the study. Hence, this study aimed to (i) compare and evaluate different yield-based drought-tolerance screening indices in a very large population, (ii) determine the efficiency of tolerance indices to classify barley genotypes, (iii) interpret interrelationships among the tolerance indices by biplot analysis.

\section{MATERIAL AND METHODS}

A set of 121 barley landraces, advanced breeding lines, and varieties was compiled from Seed and Plant Improvement Institute (SPII), Iran. The accessions were geographically originated from 12 countries (United Kingdom, Iran, Egypt, China, USA, India, Pakistan, Algeria, Ethiopia, Turkey, Spain, and Russia) (Table 1). To minimize the heterogeneity of landraces, the ear-to-row pure line selection method was applied at the Dryland Agricultural Research Institute (DARI). The genotypes were planted in two distinct water treatments (drought stress and non-stress) in the experimental field of DARI under lattice square $(11 \times 11)$ design with two replications, in autumn 2014. The plants of drought stress treatment were subjected to moisture stress from the booting stage to maturity. Each plot consisted of 6 rows of $2 \mathrm{~m}$ long and $0.20 \mathrm{~m}$ apart. At harvest, the yield of $1 \mathrm{~m}^{2}$ was used to measure potential yield (Yp) and stress yield (Ys) $\left(\mathrm{g} \mathrm{m}^{-2}\right)$.

Drought tolerance indices were calculated for lines based on grain yield $\left(\mathrm{g}\right.$ plot $\left.^{-1}\right)$ using the following relationships. Where Yp and Ys were the yield of each genotype under non-stress and stress conditions, respectively. $\hat{Y} p$ and $\hat{Y} s$ represent yield mean in non-stress and stress conditions for all genotypes, respectively.

$$
\begin{aligned}
& \mathrm{SSI}=[1-(\mathrm{Ys} / \mathrm{Yp})] /[1-(\hat{\mathrm{Y} p} / \hat{\mathrm{Y}} \mathrm{s})] \\
& \mathrm{TOL}=\mathrm{Yp}-\mathrm{Ys} \\
& \mathrm{MP}=(\mathrm{Yp}+\mathrm{Ys}) / 2 \\
& \mathrm{GMP}=(\mathrm{Yp} \times \mathrm{Ys})^{1 / 2} \\
& \mathrm{STI}=(\mathrm{Yp} \times \mathrm{Ys}) /(\hat{\mathrm{Y} p})^{2} \\
& \mathrm{YI}=\mathrm{Ys} / \hat{\mathrm{Y} s} \\
& \mathrm{YSI}=\mathrm{Ys} / \mathrm{Yp} \\
& \mathrm{HM}=2(\mathrm{Yp} \times \mathrm{Ys}) /(\mathrm{Yp}+\mathrm{Ys}) \\
& \mathrm{SDI}=(\mathrm{Yp}-\mathrm{Ys}) / \mathrm{Yp} \\
& \mathrm{DI}=\mathrm{Ys} \times[(\mathrm{Ys} / \mathrm{Yp}) / \hat{\mathrm{Y}} \mathrm{s}] \\
& \mathrm{RDI}=(\mathrm{Ys} / \mathrm{Yp}) /(\hat{\mathrm{Y}} \mathrm{s} / \mathrm{Y} \mathrm{p}) \\
& \mathrm{SSPI}=[(\mathrm{Yp}-\mathrm{Ys}) / 2 \hat{\mathrm{Y}}] \times 100
\end{aligned}
$$

The data were tested for skewness, kurtosis, homogeneity of variance, and normality by GenStat 12.0 statistical software. Then, correlation analysis between grain yield and drought tolerance indices was performed to determine the best drought-tolerant indices. Principal component analysis (PCA) was performed based on the observations. The correlation analysis and principal component biplot analysis were performed in SPSS and GenStat software, respectively. 
Table 1. Distribution of 121 barley landraces, advanced breeding lines and varieties used in this study according to their origin.

\begin{tabular}{|c|c|c|c|c|c|c|c|c|}
\hline Gen. & $\begin{array}{l}\text { GB } \\
\text { number } \\
\text { (KC) }\end{array}$ & Origin & Gen. & $\begin{array}{l}\text { GB } \\
\text { number } \\
(\mathrm{KC})\end{array}$ & Origin & Gen. & GB number (KC) & Origin \\
\hline 1 & 71411 & UK & 42 & 72498 & IRAN & 83 & 72726 & IRAN \\
\hline 2 & 71411 & UK & 43 & 72498 & IRAN & 84 & 72372 & CHINA \\
\hline 3 & 71426 & ALGERIA & 44 & 72500 & IRAN & 85 & 72382 & CHINA \\
\hline 4 & 71426 & ALGERIA & 45 & 72520 & IRAN & 86 & 72472 & IRAN \\
\hline 5 & 71482 & USA & 46 & 72522 & IRAN & 87 & 72472 & IRAN \\
\hline 6 & 71530 & RUSSIA & 47 & 72524 & IRAN & 88 & 72482 & IRAN \\
\hline 7 & 71530 & RUSSIA & 48 & 72524 & IRAN & 89 & 72553 & AZERBAIJAN \\
\hline 8 & 71538 & SPAIN & 49 & 72524 & IRAN & 90 & 72588 & IRAN \\
\hline 9 & 71538 & SPAIN & 50 & 72545 & IRAN & 91 & 72646 & IRAN \\
\hline 10 & 71557 & EGYPT & 51 & 72546 & IRAN & 92 & 72646 & IRAN \\
\hline 11 & 71576 & EGYPT & 52 & 72550 & USA & 93 & 72680 & IRAN \\
\hline 12 & 71608 & EGYPT & 53 & 72557 & AZERBAIJAN & 94 & 72680 & IRAN \\
\hline 13 & 71657 & EGYPT & 54 & 72557 & AZERBAIJAN & 95 & 72686 & IRAN \\
\hline 14 & 71663 & INDIA & 55 & 72562 & IRAN & 96 & 72704 & IRAN \\
\hline 15 & 71704 & ETHIOPIA & 56 & 72565 & IRAN & 97 & 72744 & IRAN \\
\hline 16 & 71850 & RUSSIA & 57 & 72566 & IRAN & 98 & 72747 & IRAN \\
\hline 17 & 71938 & PAKISTAN & 58 & 72566 & IRAN & 99 & $\begin{array}{l}\text { CWB117-77-9- } \\
\text { 7/3/TOKA }\end{array}$ & UNKNOWN \\
\hline 18 & 71938 & PAKISTAN & 59 & 72566 & IRAN & 100 & Tokak/Demir-2 & UNKNOWN \\
\hline 19 & 72113 & CHINA & 60 & 72568 & IRAN & 101 & $\begin{array}{l}\text { Zarjau/80- } \\
5151 / / \mathrm{DZ}-40-\end{array}$ & UNKNOWN \\
\hline 20 & 72295 & CHINA & 61 & 72581 & IRAN & 102 & $\begin{array}{l}\text { AZE-Lerik-ICB- } \\
123363 /\end{array}$ & UNKNOWN \\
\hline 21 & 72295 & CHINA & 62 & 72584 & IRAN & 103 & $\begin{array}{l}\text { CWB117-5-9- } \\
\text { 5//CWB1 }\end{array}$ & UNKNOWN \\
\hline 22 & 72295 & CHINA & 63 & 72587 & IRAN & 104 & $\begin{array}{l}\text { Ste/Antares//YE } \\
\text { A762- }\end{array}$ & UNKNOWN \\
\hline 23 & 72322 & CHINA & 64 & 72602 & IRAN & 105 & $\begin{array}{l}\text { Alpha/Gumhuri } \\
\text { yet//Sonja }\end{array}$ & UNKNOWN \\
\hline 24 & 72322 & CHINA & 65 & 72611 & IRAN & 106 & Makoee & IRAN \\
\hline 25 & 72322 & CHINA & 66 & 72646 & IRAN & 107 & Sahand & IRAN \\
\hline 26 & 72322 & CHINA & 67 & 72647 & IRAN & 108 & Abidar & IRAN \\
\hline 27 & 72368 & CHINA & 68 & 72649 & IRAN & 109 & Dayton/Ranney & ICARDA \\
\hline 28 & 72368 & CHINA & 69 & 72650 & IRAN & 110 & Yea/168 & ICARDA \\
\hline 29 & 72368 & CHINA & 70 & 72653 & IRAN & 111 & Denmark & ICARDA \\
\hline 30 & 72368 & CHINA & 71 & 72655 & IRAN & 112 & Obruk-86 & TURKEY \\
\hline 31 & 72406 & CHINA & 72 & 72664 & IRAN & 113 & UNKNOWN & UNKNOWN \\
\hline 32 & 72406 & CHINA & 73 & 72665 & IRAN & 114 & Bulbul & TURKEY \\
\hline 33 & 72439 & CHINA & 74 & 72666 & IRAN & 115 & Dicktoo & RUSSIA \\
\hline 34 & 72439 & CHINA & 75 & 72668 & IRAN & 116 & Radical & RUSSIA \\
\hline 35 & 72439 & CHINA & 76 & 72672 & IRAN & 117 & Dobrynya & RUSSIA \\
\hline 36 & 72466 & $\begin{array}{l}\text { IRAN- } \\
\text { MIYANDOAB }\end{array}$ & 77 & 72673 & IRAN & 118 & UNKNOWN & UNKNOWN \\
\hline 37 & 72472 & IRAN & 78 & 72674 & IRAN & 119 & UNKNOWN & UNKNOWN \\
\hline 38 & 72480 & IRAN-Karand & 79 & 72675 & IRAN & 120 & $\begin{array}{l}\text { ChiC/An57//Alb } \\
\text { ert }\end{array}$ & UNKNOWN \\
\hline 39 & 72480 & IRAN & 80 & 72684 & IRAN & 121 & $\begin{array}{l}\text { Pamir-65/Pamir- } \\
15\end{array}$ & UNKNOWN \\
\hline 40 & 72488 & IRAN & 81 & 72689 & IRAN & & & \\
\hline 41 & 72494 & IRAN-Gazvin & 82 & 72703 & IRAN & & & \\
\hline
\end{tabular}


Evaluation of drought

\section{RESULTS AND DISCUSSIONS}

Based on analysis of variance, there were highly significant differences for yield on nonstress (Yp) and drought stress (Ys) conditions as well as for all drought tolerance indices, but tolerance (TOL) and stress susceptibility percentage indices (SSPI) (Table 2), which indicated that genotypes were differing for genes controlling yield and drought tolerance indices
FEIZI, M. et al.

( GHOLIPOURI et al., 2009; YAGDI; SOZEN, 2009; ANWAR et al., 2011). Genotypic coefficient of variability $(\mathrm{GCV} \%)$, phenotypic coefficient of variation $(\mathrm{PCV} \%)$, and broad-sense heritability $\left(\mathrm{h}^{2}\right)$ were high for Yp, Ys, and all the indices but yield stability index (YSI) and relative drought index (RDI). Hence, a great improvement in these indices can be possible through screening under drought stress conditions (SABA et al., 2010; ANWAR et al., 2011).

Table 2. Mean square, genotypic coefficient of variation (GCV\%), phenotypic coefficient of variation $(\mathrm{PCV} \%)$, heritability in a broad sense $\left(\mathrm{h}^{2}\right.$, in $\left.\%\right)$ of $\mathrm{Yp}, \mathrm{Ys}$, and drought tolerance indices.

\begin{tabular}{|c|c|c|c|c|c|c|}
\hline Trait & $\begin{array}{l}\text { Mean Squ } \\
\text { Genotype } \\
(\mathrm{df}=120)\end{array}$ & $\begin{array}{l}\text { Error } \\
(\mathrm{df}=120)\end{array}$ & $\begin{array}{l}\mathrm{CV} \\
(\%)\end{array}$ & $\mathrm{GCV} \%$ & $\mathrm{PCV} \%$ & $h^{2}$ \\
\hline $\begin{array}{l}\text { Grain yield }\left(\mathrm{g} \text { plot }^{-1}\right) \text { under favorable } \\
\text { conditions }(Y \mathrm{p})\end{array}$ & $16904 * *$ & 3448 & 12 & 17 & 19 & 80 \\
\hline $\begin{array}{l}\text { Grain yield }\left(\mathrm{g} \text { plot }^{-1}\right) \text { under drought } \\
\text { conditions (Ys) }\end{array}$ & $15099 * *$ & 2407 & 12 & 20 & 21 & 84 \\
\hline Stress susceptibility index (SSI) & $0.5604 *$ & 0.3944 & 50 & 22 & 41 & 30 \\
\hline Tolerance (TOL) & $2535^{\mathrm{ns}}$ & 2173 & 58 & 17 & 44 & 14 \\
\hline Mean productivity (MP) & $15368 * *$ & 2385 & 11 & 18 & 20 & 84 \\
\hline Geometric mean productivity (GMP) & $15421 * *$ & 2372 & 11 & 18 & 20 & 85 \\
\hline Stress tolerance index (STI) & $0.208 * *$ & 0.038 & 22 & 33 & 37 & 82 \\
\hline Yield index (YI) & $0.085 * *$ & 0.014 & 12 & 19 & 21 & 84 \\
\hline Yield stability index (YSI) & $0.01 *$ & 0.007 & 10 & 5 & 8 & 30 \\
\hline Harmonic mean (HM) & $15487 * *$ & 2375 & 11 & 18 & 20 & 85 \\
\hline Sensitivity drought index (SDI) & $0.01 *$ & 0.007 & 50 & 22 & 41 & 30 \\
\hline Drought resistance index (DI) & $0.089 * *$ & 0.021 & 18 & 23 & 26 & 76 \\
\hline Relative drought index (RDI) & $0.013^{*}$ & 0.009 & 10 & 5 & 8 & 30 \\
\hline $\begin{array}{l}\text { Stress susceptibility percentage index } \\
\text { (SSPI) }\end{array}$ & $26.9^{\mathrm{ns}}$ & 23.1 & 58 & 17 & 44 & 14 \\
\hline
\end{tabular}

* and ** Significant respectively at $\mathrm{p}<0.05$ and $\mathrm{p}<0.01 ; \mathrm{ns}-$ not significant.

There was a great variation among 121 barley genotypes for the calculated drought tolerance indices based on grain yield under drought stress and non-stress conditions, indicating the presence of high genetic variability among the genotypes (Table 3). The average grain yield under non-stress and stress conditions were 489 and $408 \mathrm{~g}$ plot $^{-1}$, respectively, with a decrease of $17 \%$. Line 107 had the highest grain yield under both conditions. This line had lower than all genotypes average SSI (0.76), TOL (65), SDI (0.1), SSPI (7); had higher than average YSI (0.9); and had maximum MP (628), GMP (627), STI (1.66), YI (1.41), HM (626), DI (1.27) and RDI (1.04). According to SSI, line 107 was considered as genotypes with low drought susceptibility and high yield stability under both stress and non-stress conditions. Moreover, the maximum STI amount of this line proves the power of the STI index in identifying tolerant genotypes that produce high yield under both conditions (FERNANDEZ, 1992). The lower value of TOL means minor yield reduction under stress conditions and lower the drought sensitivity. The genotypes' ranking for MP, GMP, and HM indices were almost identical (Table 3), which suggested that these three indices were equal for screening genotypes (RICHARDS, 1996; ANWAR et al., 2011). These indices have been compared by different researchers (FERNANDEZ, 1992; RICHARDS, 1996) and their genetic parameters have also been studied (DARVISHZADEH et al., 2011). 
Table 3. Descriptive statistics of drought indices in 121 barley genotypes.

\begin{tabular}{lcccc}
\hline Drought index & Minimum & Maximum & Mean & $\begin{array}{c}\text { Standard } \\
\text { deviation }\end{array}$ \\
\hline Grain yield $\left(\mathrm{g} \mathrm{plot}^{-1}\right.$ ) under favorable conditions (Yp) & 215 & 660 & 489 & 92 \\
Grain yield (g plot ${ }^{-1}$ ) under drought conditions (Ys) & 160 & 595 & 408 & 87 \\
Stress susceptibility index (SSI) & 0.31 & 2.37 & 1.26 & 0.54 \\
Tolerance (TOL) & 15 & 180 & 81 & 36 \\
Mean productivity (MP) & 188 & 628 & 449 & 88 \\
Geometric mean productivity (GMP) & 186 & 627 & 446 & 88 \\
Stress tolerance index (STI) & 0.15 & 1.66 & 0.88 & 0.32 \\
Yield index (YI) & 0.38 & 1.41 & 0.97 & 0.21 \\
Yield stability index (YSI) & 0.69 & 0.96 & 0.84 & 0.07 \\
Harmonic mean (HM) & 184 & 626 & 444 & 88 \\
Sensitivity drought index (SDI) & 0.04 & 0.31 & 0.17 & 0.07 \\
Drought resistance index (DI) & 0.28 & 1.27 & 0.82 & 0.21 \\
Relative drought index (RDI) & 0.80 & 1.10 & 0.96 & 0.08 \\
Stress susceptibility percentage index (SSPI) & 2 & 19 & 8.3 & 4 \\
\hline
\end{tabular}

Based on the genotypic correlation coefficient between $\mathrm{Yp}$, Ys, and other drought indices (Table 4), Yp had a very strong association with Ys $(\mathrm{r}=0.92 * *)$ that indicates high yield potential under non-stress can predict better yield under stress conditions (Figure 1). Therefore, indirect screening under stress environment would be effective based on the performance of irrigated conditions (ALI; EL-SADEK, 2016). However, this result was not in agreement with Anwar et al. (2011) and Gholipouri et al. (2009). Yp and Ys were positively and significantly correlated with
MP, GMP, STI, YI, HM, and DI indices, whereas they were negatively correlated with SSI and SDI. These results were consistent with the findings of Ali and El-Sadek (2016) in wheat, Golabadi et al. (2006) in durum wheat, Farshadfar, and Sutka (2002) in maize and Zare (2012) in barley. Highly positively correlated indices with both the Ys and Yp would be the most suitable indices in screening stress-tolerant genotypes (Farshadfar; Javadinia, 2011).

Table 4. Genotypic correlation of yield under non-stress condition (Yp), yield under drought stress (Ys), and drought tolerance indices in 121 barley genotypes.

\begin{tabular}{|c|c|c|c|c|c|c|c|c|c|c|c|c|c|}
\hline Index & $Y p$ & Ys & SSI & TOL & MP & GMP & STI & YI & YSI & HM & SDI & DI & RDI \\
\hline Ys & $0.92^{* *}$ & & & & & & & & & & & & \\
\hline SSI & -0.14 & $-0.51^{* *}$ & & & & & & & & & & & \\
\hline TOL & $0.33^{* *}$ & -0.06 & $0.88^{* *}$ & & & & & & & & & & \\
\hline MP & $0.98^{* *}$ & $0.98^{* *}$ & $-0.32^{* *}$ & 0.15 & & & & & & & & & \\
\hline GMP & $0.98^{* *}$ & $0.98^{* *}$ & $-0.34^{* *}$ & 0.13 & $0.99^{* *}$ & & & & & & & & \\
\hline STI & $0.96^{* *}$ & $0.98^{* *}$ & $-0.34^{* *}$ & 0.11 & $0.99^{* *}$ & $0.99^{* *}$ & & & & & & & \\
\hline YI & $0.92^{* *}$ & $0.99^{* *}$ & $-0.50^{* *}$ & -0.06 & $0.98^{* *}$ & $0.98^{* *}$ & $0.98^{* *}$ & & & & & & \\
\hline YSI & 0.14 & $0.50^{* *}$ & $-0.99^{* *}$ & $-0.88^{* *}$ & $0.32^{* *}$ & $0.34^{* *}$ & $0.34^{* *}$ & $0.50^{* *}$ & & & & & \\
\hline HM & $0.97^{* *}$ & $0.99^{* *}$ & $-0.36^{* *}$ & 0.11 & $0.99^{* *}$ & $0.99^{* *}$ & $0.99^{* *}$ & $0.99^{* *}$ & $0.36^{* *}$ & & & & \\
\hline SDI & -0.14 & $-0.50^{* *}$ & $0.99^{* *}$ & $0.88^{* *}$ & $-0.32^{* *}$ & $-0.34^{* *}$ & $-0.34^{* *}$ & $-0.50^{* *}$ & $-0.99^{* *}$ & $-0.36^{* *}$ & & & \\
\hline DI & $0.78^{* *}$ & $0.96^{* *}$ & $-0.72^{* *}$ & $-0.33^{* *}$ & $0.89^{* *}$ & $0.90^{* *}$ & $0.89^{* *}$ & $0.96^{* *}$ & $0.72^{* *}$ & $0.90^{* *}$ & $-0.72^{* *}$ & & \\
\hline RDI & 0.14 & $0.51^{* *}$ & $-0.99^{* *}$ & $-0.87^{* *}$ & $0.32^{* *}$ & $0.34^{* *}$ & $0.34^{* *}$ & $0.51^{* *}$ & $0.99^{* *}$ & $0.36^{* *}$ & $-0.99^{* *}$ & $0.72^{* *}$ & \\
\hline SSPI & $0.33^{* *}$ & -0.06 & $0.87^{* *}$ & $0.99^{* *}$ & 0.14 & 0.12 & 0.11 & -0.06 & $-0.87^{* *}$ & 0.10 & $0.87^{* *}$ & $-0.33^{* *}$ & $-0.87^{* *}$ \\
\hline
\end{tabular}

* and ** Significant respectively at $\mathrm{p}<0.05$ and $\mathrm{p}<0.01$. (Pearson correlation method) 


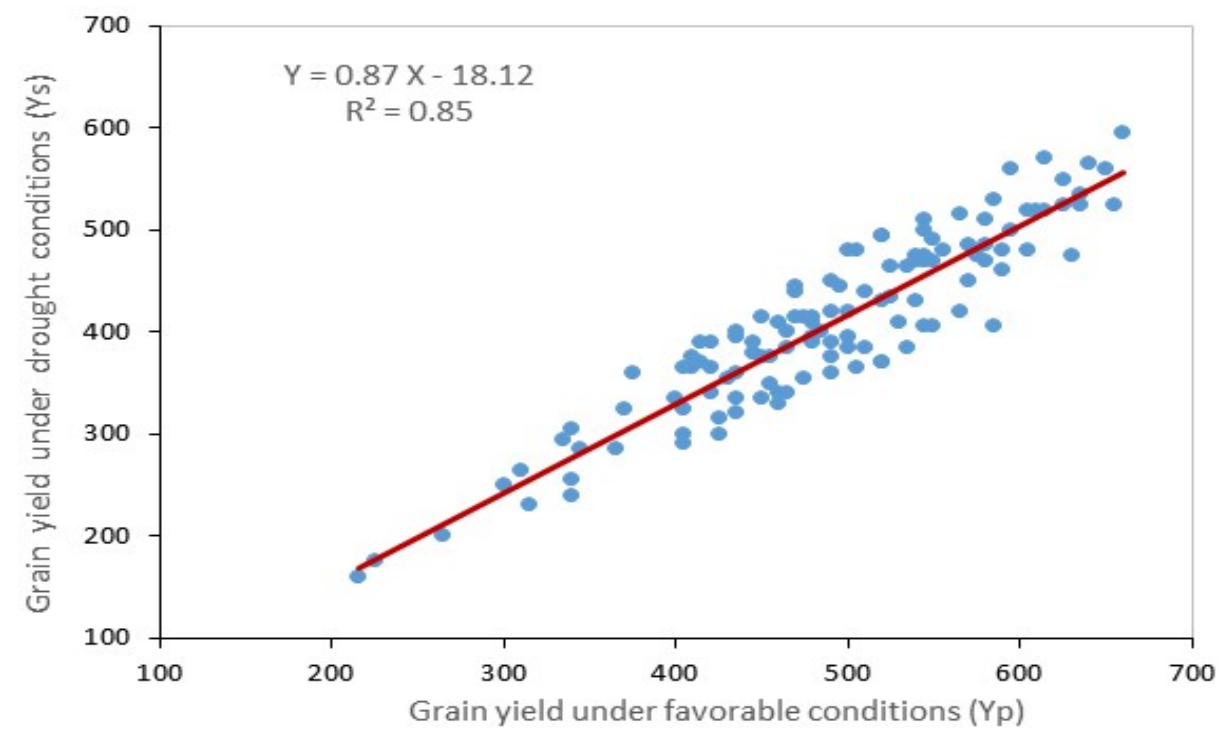

Figure 1. The relationship between grain yield produced under non-stress and drought stress conditions in 121 barley genotypes.

In principal component analysis (PCA), the first PC explained $64 \%$ of total variation with Yp, Ys, MP, GMP, STI, YI, HM, and DI. Thus, the first dimension can be named as the yield potential and drought tolerance. Based on the positive and high value of PC-1 on biplot, the selected genotypes would be high yielding under non-stress and stress conditions. As a result, line 107 with the biggest PC-1 was more suitable for both non-stress and stress conditions (Table 5 and Figure 2). Genotypes with lower PC-1 and larger PC-2 scores (such as line 104 with 0.69 yield stability score) had unstable yield, whereas genotypes with bigger PC1 and smaller PC-2 scores (such as line 90 with
0.96 yield stability score) were more stable genotypes (KAYA et al., 2002). The second PC explained $35.6 \%$ of the total variation and had a positive correlation with SSI, TOL, SDI, and SSPI. Therefore, PC-2 can be named as a stress-tolerant dimension and it could differentiate the tolerant genotypes from susceptible ones. Hence, screening of genotypes with high PC-1 and low PC-2 would be appropriate for both non-stress and stress conditions (KAYA et al., 2006), as can be seen in line 107. Similar results were reported by Golabadi et al. (2006), Farshadfar and Sutka (2002) obtained similar results in multivariate analysis of drought tolerance in substitution lines.

Table 5. Principal components analysis for drought tolerance indices in 121 barley genotypes.

\begin{tabular}{|c|c|c|c|c|}
\hline Index & PCA-1 & PCA-2 & PCA-3 & PCA-4 \\
\hline Grain yield $\left(\mathrm{g} \mathrm{plot}^{-1}\right)$ under favorable conditions (Yp) & 0.26 & 0.28 & 0.13 & 0.09 \\
\hline Grain yield $\left(\mathrm{g} \mathrm{plot}^{-1}\right)$ under drought conditions (Ys) & 0.32 & 0.12 & -0.06 & 0.17 \\
\hline Stress susceptibility index (SSI) & -0.24 & 0.31 & -0.28 & 0.13 \\
\hline Tolerance (TOL) & -0.11 & 0.42 & 0.47 & -0.17 \\
\hline Mean productivity (MP) & 0.30 & 0.21 & 0.04 & 0.13 \\
\hline Geometric mean productivity (GMP) & 0.30 & 0.20 & 0.03 & 0.13 \\
\hline Stress tolerance index (STI) & 0.30 & 0.20 & -0.43 & -0.83 \\
\hline Yield index (YI) & 0.32 & 0.12 & -0.06 & 0.17 \\
\hline Yield stability index (YSI) & 0.24 & -0.31 & 0.28 & -0.13 \\
\hline Harmonic mean (HM) & 0.30 & 0.19 & 0.02 & 0.12 \\
\hline Sensitivity drought index (SDI) & -0.24 & 0.31 & -0.28 & 0.13 \\
\hline Drought resistance index (DI) & 0.33 & 0.00 & -0.18 & 0.27 \\
\hline Relative drought index (RDI) & 0.24 & -0.31 & 0.28 & -0.13 \\
\hline Stress susceptibility percentage index (SSPI) & -0.11 & 0.42 & 0.47 & -0.17 \\
\hline Latent roots & 8.95 & 4.98 & 0.06 & 0.01 \\
\hline Percentage of variation & 63.9 & 35.6 & 0.4 & 0.1 \\
\hline Cumulative percentage & 64.3 & 99.5 & 99.9 & 100 \\
\hline
\end{tabular}




\section{Evaluation of drought}

A combination of indices may provide a more useful criterion in screening drought tolerance genotypes; however, the study of a correlation coefficient can find out the degree of overall linear association between any two attributes. Hence, a better method than the correlation approach such as biplot would be useful to recognize the superior genotypes for both stress and non-stress conditions. Based on the cosine of the angle between indices vectors in Figure 2 (YAN; RAJCAN, 2002), there was i) a strong negative association between RDI
FEIZI, M. et al.

and YSI with SDI, SSI, TOL, and SSPI, as indicated by the large angles between their vectors, (ii) almost no correlation of Yp and TOL with SDI and SSI, as well as Ys and YI with TOL and SSPI, (iii) a positive association among Yp, Ys, YI, HM, STI, GMP, and MP indices as indicated by the acute angles. The results obtained from the biplot graph confirmed correlation analysis (Figure 2). The results of biplot were almost consistent with correlation coefficients analysis (Table 4).

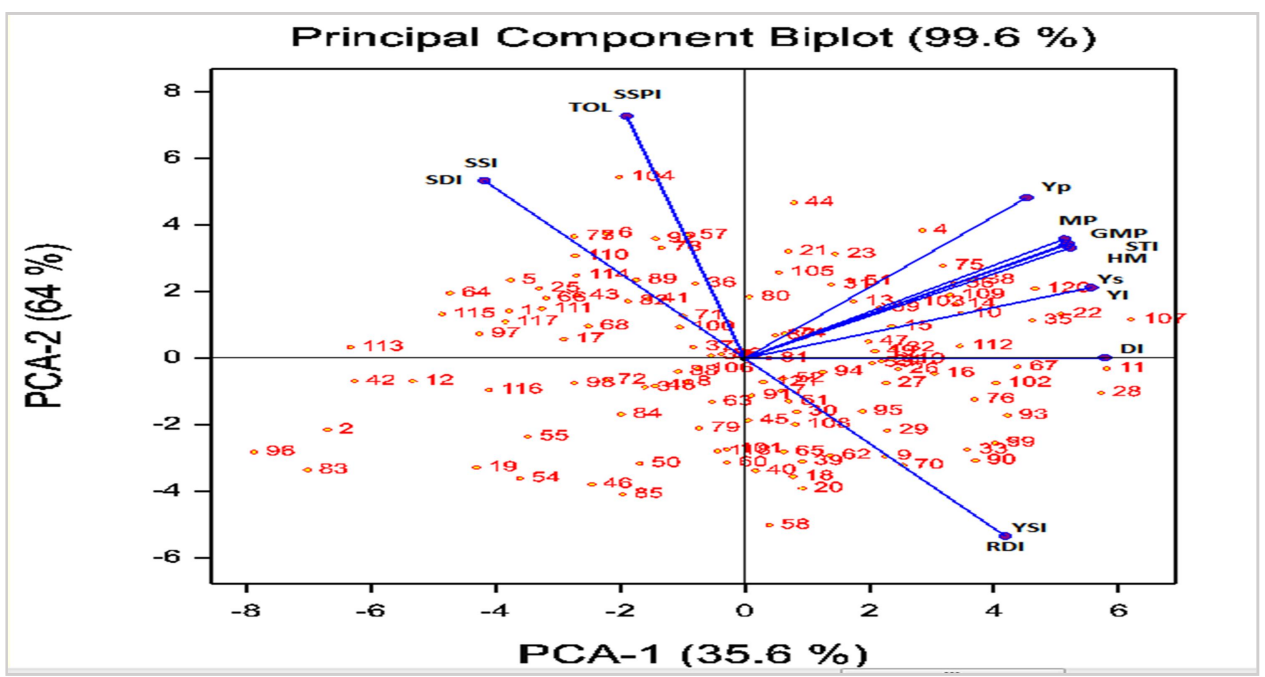

Figure 2. The genotype by trait biplots of the first two principal components of 121 barley genotypes. The indices are spelled out in capital letters, and each genotype is represented by numbers.

In this study, drought stress declined 20\% average yield of the genotypes; however, some of them showed tolerance to drought, which suggests the existence of genetic variability for drought resistance among barley genotypes.

A large variation was found in drought tolerance index values of genotypes for grain yield, and significantly positive correlation was observed between Yp and Ys with the measured indices. A high STI score indicates higher stress tolerance and high yield potential as it was observed in Line 107 with the maximum STI score (1.66) among 121 genotypes.

Based on Fernandez's theory (1992), a proper criterion could identify genotypes with a steady superiority and has a high correlation with yield in both non-stress and stress conditions. Hence, MP, GMP, STI, YI, HM, and DI indices with the most positive and significant correlation with the yield at both non-stress and stress environments would be better indices to screen barley genotypes, although none of the indices could undoubtedly identify high yield genotypes under both conditions. Based on these indices, and the results of principal component and biplot analysis, the most tolerant and favorite genotypes were in Line 107, that had the maximum scores of these indices. On the other hand, the most sensitive genotypes based on these indices were in Line 96 that had the lowest score of these indices. 
RESUMO: O cultivo de cevada para áreas secas exige uma avaliação confiável da variabilidade da tolerância à seca entre os germoplasmas reprodutores. Assim, 121 linhagens crioulas de cevada (linhas de reprodução avançada e variedades) foram avaliadas em campo sob condições sem estresse e com estresse de umidade do solo, utilizando-se para isso um arranjo experimental de malha quadrada $(11 \times 11)$, com duas repetições para cada conjunto de ensaios. Foram utilizados 12 índices de tolerância à seca (SSI, TOL, MP, GMP, STI, YI, YSI, HM, SDI, DI, RDI e SSPI), com base no rendimento de grãos sob condições normais sem estresse (Yp) e com estresse de seca (Ys). A análise de variância mostrou uma variação genética significativa entre os genótipos para todos os índices, com exceção dos índices TOL e SSPI. Yp teve uma associação muito forte com Ys $(r=0,92 * *)$, o que indica que o potencial de alto rendimento sob condições sem estresse pode prever melhor rendimento sob condições de estresse. Yp e Ys foram positivamente e significativamente correlacionados com os índices MP, GMP, STI, YI, HM e DI, enquanto, foram correlacionados negativamente com os índices SSI e SDI. Na análise de componentes principais (PCA), o primeiro PC explicou 64\% da variação total com Yp, Ys, MP, GMP, STI, YI, HM e DI. O segundo PC explicou 35,6\% da variação total e apresentou correlação positiva com SSI, TOL, SDI e SSPI. Pode-se concluir que, os índices MP, GMP, STI, YI, HM e DI com a correlação mais positiva e significativa com a produção nos ambientes sem estresse e com estresse seriam melhores índices para a seleção de genótipos de cevada, embora nenhum dos índices pudesse concretamente identificar genótipos de alto rendimento sob ambas as condições.

PALAVRAS-CHAVE: Biplot. Análise do componente principal. Germoplasma. Produção.

\section{REFERENCES}

ABEBE, A.; M. A. BRICK.; R. A. Kirkby. Comparison of selection indices to identify productive dry bean lines under diverse environmental conditions. Field Crops Research, Amsterdam, v. 58, n. 1, p. 15-23, 1998. https://doi.org/10.1016/s0378-4290(98)00082-3

ALI, M. B.; A. N. EL-SADEK. Evaluation of drought tolerance indices for wheat (Triticum aestivum L.) under irrigated and rainfed conditions. Communications in Biometry and Crop Science, Uttar Pradesh, v. 11, 7789, 2016.

ANWAR, J.; G. M. SUBHANI.; M. HUSSAIN.; J. AHMAD.; M. HUSSAIN.; M. Munir. Drought tolerance indices and their correlation with yield in exotic wheat genotypes. Pakistanian Journal of Botany, Karachi, v. 43, 1527-1530, 2011.

ASSAHA, D. V .M.; L. LIU.; A. UEDA.; T. NAGAOKA.; H. SANEOKA. Effects of drought stress on growth, solute accumulation and membrane stability of leafy vegetable, huckleberry (Solanum scabrum Mill.). Journal of environmental biology, Vikas Nagar Kursi Rd Lucknow, v. 37, 107-114, 2016.

https://doi.org/10.17957/ijab/15.0052

BLUM, A. Crop responses to drought and the interpretation of adaptation. Plant Growth Regulation, New York. v. 20, 135-148, 1996. https://doi.org/10.1007/bf00024010

DARVISHZADEH, R.; A. PIRZAD.; I. BERNOUSI.; B. ABDOLLAHI MANDOULAKANI.; H. AZIZI.; N. AKHONDI.; S. POORMOHAMMAD KIANI.; A. Sarrafi. Genetic properties of drought tolerance indices in sunflower. Acta Agriculturae Scandinavica, Section B-Soil \& Plant Science. United Kingdom, v. 61, 593601, 2011. https://doi.org/10.1080/09064710.2010.530292

FARSHADFAR, E.; J. SUTKA. Screening drought tolerance criteria in maize. Acta Agronomica Hungarica. Kiado, v. 50, 411-416, 2002. https://doi.org/10.1556/aagr.50.2002.4.3

FARSHADFAR, E.; J. JAVADINIA. Evaluation of chickpea (Cicer arietinum L.) genotypes for drought tolerance. Seed And Plant Improvement Journal, Karaj, v. 27, 2011. 
FERNANDEZ, G. C. J. Effective selection criteria for assessing plant stress tolerance. Crop Science, Madison, v. 28, 13-16, 1992.

GHOLIPOURI, A.; M. SEDGHI.; R. S. SHARIFI.; N. M. NAZARI. Evaluation of Drought Tolerance Indices and their Relationship whit Grain Yield in Wheat Cultivars. Recent Research in Science and

Technology,Tehran, v. 1, 2009.

GOLABADI, M.; A. ARZANI.; S. A. M. MIRMOHAMMADIMAIBODI. Assessment of drought tolerance in segregating populations in durum wheat. African Journal of Agricultural Research, Sari, v. 1, 162-171, 2006.

JIANG, Y.; B. HUANG. Effects of drought or heat stress alone and in combination on Kentucky bluegrass. Crop Science, Madison, v. 40, 1358-1362, 2000. https://doi.org/10.2135/cropsci2000.4051358x

KAYA, Y.; Ç. PALTA.; S. TANER. Additive main effects and multiplicative interactions analysis of yield performances in bread wheat genotypes across environments. Turkish Journal of Agriculture and Forestry,Ankara, v. 26, 275-279, 2002.

KAYA, Y.; M. AKCURA.; S. TANER. GGE-biplot analysis of multienvironment yield trials in bread wheat. Turkish Journal of Agriculture and Forestry, Ankara, v. 30, 325-337, 2006.

KIRIGWI, F.M.; M. VAN GINKEL.; R. TRETHOWAN.; R.G. SEARS.; S. RAJARAM.; G.M. PAULSEN. Evaluation of selection strategies for wheat adaptation across water regimes. Euphytica, Netherlands, v. 135, 361-371, 2004. https://doi.org/10.1023/b:euph.0000013375.66104.04

KUTLU, I.; G. Kinaci. Evaluation of drought resistance indicates for yield and its components in three triticale cultivars. Journal of Tekirdag Agricultural Faculty. Turkey, v. 7, 95-103, 2010.

MOOSAVI, S.; B. YAZDI SAMADI.; M. NAGHAVI.; A. ZALI.; H. DASHTI.; A. POURSHAHBAZI. Introduction of new indices to identify relative drought tolerance and resistance in wheat genotypes.

Desert,Tehran, v. 12, 165-178, 2008.

MURSALOVA, J.; Z. AKPAROV.; J. OJAGHI.; M. ELDAROV.; S. BELEN.; N. GUMMADOV.; A. MORGOUNOV. Evaluation of drought tolerance of winter bread wheat genotypes underdrip irrigation and rain-fed conditions. Turkish Journal of Agriculture and Forestry,Ankara, v. 39, 817-824, 2015. https://doi.org/10.3906/tar-1407-152

NAZARI, L.; H. PAKNIYAT. Assessment of drought tolerance in barley genotypes. Journal of Applied Sciences, Bangladesh, v. 10, 151-156, 2010. https://doi.org/10.3923/jas.2010.151.156

REDDY, A. R.; K. V. CHAITANYA.; M. VIVEKANANDAN. Drought-induced responses of photosynthesis and antioxidant metabolism in higher plants. Journal of Plant Physiology, Munich, v. 161, 1189-1202, 2004. https://doi.org/10.1016/j.jplph.2004.01.013

RICHARDS, R. A. Defining selection criteria to improve yield under drought, In: E. Belhassen, (ed.) Drought Tolerance in Higher Plants: Genetical, Physiological and Molecular Biological Analysis, 79-88, 1996. https://doi.org/10.1007/978-94-017-1299-6_10

SABA, J.; M. MOGHADAM.; K. GHASSEMI.; M. NISHABOURI. Genetic properties of drought resistance indices. Journal of Agricultural Science and Technology, v. 3, 43-49, 2010.

SIO-SE MARDEH, A.; A. AHMADI.; K. POUSTINI.; V. MOHAMMADI. Evaluation of drought resistance indices under various environmental conditions. Field Crops Research, Amsterdam, v. 98, 222-229, 2006. https://doi.org/10.1016/j.fcr.2006.02.001 
TARDIEU, F., B. PARENT.; C.F. CALDRIRA.; C. WELCKER. Genetic and physiological controls of growth under water deficit. Plant Physiology, Munich, v. 164, 1628-1635, 2014.

https://doi.org/10.1104/pp.113.233353

VON KORFF, M.; S. GRANDO.; A. DEL GRECO.; D. THIS.; M. BAUM.; S. CECCARELLI. Quantitative trait loci associated with adaptation to Mediterranean dryland conditions in barley. Theoretical and Applied Genetics, New York, v. 117, 653-669, 2008. https://doi.org/10.1007/s00122-008-0787-2

WEHNER, G.; C. BALKO.; K. HUMBECK.; E. ZYPRIAN.; F. ORDON. Expression profiling of genes involved in drought stress and leaf senescence in juvenile barley. BMC Plant Biology, London, v. 16, 2016. https://doi.org/10.1186/s12870-015-0701-4

YAGDI, K.; E. SOZEN. Heritability, variance components and correlations of yield and quality traits in durum wheat (Triticum durum Desf.). Pakistanian Journal of Botany, v. 41, 753-759, 2009.

YAN, W.; I. RAJCAN. Biplot analysis of test sites and trait relations of soybean in Ontario. Crop Science, Madison, v. 42, 11-20, 2002. https://doi.org/10.2135/cropsci2002.1100

ZARE, M. Evaluation of drought tolerance indices for the selection of Iranian barley (Hordeum vulgare) cultivars. African Journal of Biotechnology, v. 11, 15975-15981, 2012. https://doi.org/10.5897/ajb12.2127 